\title{
Determining Proper Row Orientation and Seeding Population for Soybean Production
}

\author{
Richard E. Turner \\ Mississippi State University \\ M. Wayne Ebelhar \\ Mississippi State University \\ Bobby R. Golden \\ Mississippi State University \\ Trenton Irby \\ Mississippi State University \\ Teresa Wilkerson \\ Mississippi State University \\ Steve Martin \\ Mississippi State University
}

Soybean planting seed cost is the greatest expense in most growing seasons. The objective of this study was to evaluate row orientations on 40-in rows (single-row [SR] vs twin-row [TR]) and planting populations (78,400, 104,500, 130,800 and 156,800) seed/acre. In 2017 and 2018 a field study in the Mississippi Delta was designed to determine whether canopy closure was impacted by treatment and the effect on yield and plant characteristics. Mapping data showed that soybean yield was maintained at low seeding rates. Data indicated that planting population could be reduced provided the existing stand was uniform in emergence.

Keywords: Soybean, Planting Patterns, Orientation, Population

\section{INTRODUCTION}

Soybean [Glycine $\max (\mathrm{L}$.$) ] is a major row crop in Mississippi planted on 2.2$ million acres in 2017. Mississippi crops are predominantly grown on raised beds that are typically on a 38 to 40 inch row spacing. Raised beds are necessary for two main reasons: i) getting the water off the field in early spring (drainage) ii) putting water on the field (irrigation) during the summer. In Mississippi, cotton is grown 
almost exclusively on the wide row spacing. Many cotton (Gossypium hirsutum) acres are rotated with grain crops this leads to all crops grown on wide rows for equipment simplicity purposes and to avoid compaction issues associated with narrower row spacing.

Many producers in Mississippi have converted to a twin-row (TR) planting orientation that results in a faster canopy coverage that helps prevent resistant weed species native to Mississippi. Mississippi State University currently recommends a planting population of 120,000 seeds acre; however there is no row orientation recommendation.

\section{LITERATURE REVIEW}

Multiple studies from northern United States have shown the advantage to using row spacing < 30-in (Green et al., 1977; Ryder and Beuerlein, 1979; Costa et al., 1980; Wilcox, 1980; Cooper, 1981). Doss and Thurlow, (1974) and Heatherly, (1981) showed little advantage in the southern United States when using row width < 35 in. However, Akhanda et al., (1976); Beatty et al., (1982); Boquet et al., (1982); Thurlow and Pitts, (1983) all showed the advantage of narrow row width, 18 to 20 in.

Under optimum growing conditions in Kansas, similar soybean grain yield was achieved with 30-in rows compared to 8 -in rows, with only $50 \%$ of the usual seeding rate required to maximize yield on 8 -in rows (Devlin et al., 1995). Devlin et al., (1995) also noted that if soil moisture was limiting then grain yield was not influenced by seeding rate and 30-in rows outperformed 8-in rows.

When comparing determinate and indeterminate soybean varieties at three row spacings $(10,20$ and 30 in) Elmore, (1998) reported that under irrigated conditions 20-in rows yielded greatest for both determinate and indeterminate soybean. Consistently, the 20-in row spacing produced greater yield across all planting populations being analyzed in Nebraska.

The advantage of using TR has been reported in soybean production (Bruns, 2011; Mascagni et al., 2008). Mascagni et al., (2008) in Louisiana observed a 0 to $13 \%$ yield increase using TR compared to SR configuration. Similarly, Bruns, (2011) reported fewer pods per plant when using TR; however, TR produced more plants/ft and more seed/ft on a Beulah fine sandy loam. The increase in plants/ft is likely due to increasing LAI that results in greater survivability of soybean seedlings.

Stivers and Swearingin (1980) showed that soybean has the ability to compensate for low seeding rates as long as the reduced stand was uniform in emergence (short skips 1-ft compared to long skips 4- $\mathrm{ft}$ ) in northwest Indiana. In this study yield reduction ranged from $1.1 \%$ with the small skips compared to $15.3 \%$ reduction with the larger skips. Original planting populations were 12 to $14 \mathrm{seed} / \mathrm{ft}$ and thinned to a uniform 5.5, 4.3, and $3 \mathrm{seed} / \mathrm{ft}$. The soybean ability to compensate for small gaps showed the plants natural ability to compensate (increase number of branches/plant), and also increased the number of pods on those branches. Increasing seed weight also played a small role in increased grain yield with change in planting population.

Ideally, the proper planting population should provide the most seed yield per area. Planting populations that are too great limit yield, due to reduced total number of flowers (Dominguez and Hume, 1978). Dominguez and Hume, (1978) reported total number of flowers and pods per plant were reduced at high densities, mainly due to reproductive structures being aborted. Low populations provide maximum efficiency per plant, but maximum efficiency could not compensate for reduced number of plants. Consistency in planting population was key, similar yields have been achieved with a range of planting populations (Wilcox, 1974; Lueschen and Hicks, 1977; Hoggard et al., 1978; Costa et al., 1980).

Bruns, (2011) reported no change in mean number of nodes produced when comparing four seeding rates; however $15 \mathrm{seed} / \mathrm{ft}$ produced fewer pods/plant than $6 \mathrm{seed} / \mathrm{ft}$. Mascagni et al., (2008) reported no yield increase when comparing row orientation or soil textures when seeding rate was increased beyond 9 seed/ft. Ball et al., (2001) reported an inverse relationship in number of fertile nodes and planting population. Results also reported effects of planting population on mass/seed and seeds/pod to be small compared to population and pods/plant.

Like soybean, cotton has the ability to compensate by producing fruit on lateral branches. The reduced seed cost associated with approximately 16,200 less seed/acre would make using TR 
configuration an advantage in cotton production. Reddy and Boykin, (2010) reported a $6 \%$ greater yield in cotton lint produced using TR orientation compared to SR, due to more open bolls and lower total weed dry biomass. Reddy el al., (2009) noted that a cotton population of 36,400 plants acre (planted on two rows 15-in apart on 40-in beds) TR produced comparable cotton lint as 51,400 plants acre on conventional 40-in SR. However, other issues such as the ability to mechanical harvest has led to nonadoption of the system.

Recent studies on corn (Zea mays) with respect to row width and seeding populations have concluded that even northern Corn Belt states have the possibility of producing similar yields using wide rows (30 in) to narrow rows (15 in) (Farnham, 2001; Widdicombe and Thelen, 2002). Widdicombe and Thelen, (2002) noted that as planting population increased, grain moisture decreased, and grain test weight increased. Balkcom et al., (2011) reduced early season weed biomass with no preplant (PRE) herbicide and using a TR planting configuration in corn production and also increased leaf area index (LAI). No consistent yield increase was observed when using TR planting under dryland conditions.

\section{SITE DESCRIPTION AND EXPERIMENTAL DESIGN}

Research was conducted in 2017 and 2018 at the Delta Research and Extension Center, Stoneville, Mississippi on a Commerce very fine sandy loam (Fine-silty, mixed, superactive, nonacid, thermic Fluvaquentic Endoaquepts). Experimental units, 13.3 -ft wide by $82-\mathrm{ft}$ long (4 rows), were seeded with a John Deere Maxemerge 2 4-row planter (John Deere, Moline, IL) for the SR orientation. A Monosem twin row planter for TR orientation, both at a depth of 1.2-inches and at four seeding rates of 78,400, $104,500,130,800$ and 156,800 seed/acre. Beds were established on at 40-in centers for both orientations, single rows are separated by 40 -in spacing while TR is separated by a 10 -in space on the 40 -in row and a 30 -in space between the rows. The experimental design arrangement of treatments was a randomized complete block with a 2 X 4 factorial (row orientation X planting population) with eight replications. All soybean cultivars had an indeterminate growth habit and were MG 4.7. Grain yields were determined by combine-harvesting the center two rows (SR) or center four rows (TR) of each plot. Samples were collected at harvest to determine harvest moisture, bushel test weight, and seed index (100-seed weight). Individual plant samples were collected at harvest from adjoining rows for the plant component analysis.

\section{STATISTICAL ANALYSIS}

Using the PROC MIXED procedure of SAS (Statistical Analytical System Release 9.4; SAS Institute Inc., Cary, North Carolina), an analysis was conducted with row orientation and planting population serving as fixed effects and replication within year serving as random terms. Degrees of freedom were estimated using the Kenward-Roger method. Means were separated using the LSMEANS statement. Differences were considered significant for $\alpha=0.05$. If the interaction was not significant, then main effects were evaluated.

\section{CANOPY CLOSURE}

Canopy closure measurement was taken at growth stages R1 - R7 using the Canopeo Iphone application (Table 1). Measurement was taken between rows two and three (harvest rows and a nontraffic furrow). Canopy closure was always greater when utilizing TR when compared to SR. Canopy consistently increased at each stage until R5 at which point senescence began and the canopy cover began to decrease. Data showed that canopy closure was $18 \%$ greater at R1 growth stage when comparing TR to SR (Table 1). At R2 TR produced 16\% greater canopy closure when compared to SR. Growth stages R3, $\mathrm{R} 4$, and R5 resulted in 9\% greater canopy closure for TR orientation when compared to SR. Both R6 and R7 resulted in a $4 \%$ increase in canopy closure for TR when compared to SR. Time to achieve full canopy 
is critical for weed suppression. However, canopy density decline after R7 is equally important in regards to harvest moisture.

TABLE 1

THE EFFECT OF ROW ORIENTATION AND AS IT INFLUENCED CANOPY CLOSURE AT EACH REPRODUCTIVE GROWTH STAGE (R1-R7) FOR RESEARCH ESTABLISHED DURING 2017 AND 2018 AT THE DELTA RESEARCH AND EXTENSION CENTER

\begin{tabular}{ccc}
\hline Growth Stage & Single-Row & Twin-Row \\
\hline R1 & $\ldots \ldots \ldots(\ldots) \ldots \ldots . . \ldots$ \\
R2 & 42.0 & 51.0 \\
R3 & 50.9 & 60.5 \\
R4 & 73.2 & 80.5 \\
R5 & 76.7 & 83.9 \\
R6 & 82.6 & 90.6 \\
R7 & 78.4 & 81.3 \\
\hline
\end{tabular}

\section{SOYBEAN PLANT MAPPING}

The interaction of variable plant measurements associated with plant mapping is shown in Table 2 . Plant height data not shown (NS) when comparing row orientation and planting populations. Seed weight was not significantly influenced by planting population (data not shown) with the results similar to Bruns, (2011) that was also from research at Stoneville, MS. Seed weight was significantly influenced by row orientation (Table 2). Single row orientation produced significantly greater seed weight when compared to TR (Table 3). Single-row orientation produced $2 \%$ greater seed weight when compared to TR.

Total nodes per plant declined linearly as planting population increased (Table 4). The increase in total number of nodes on lower planting populations were mainly located on lateral branches. Lueschen and Hicks, (1977) reported a linear reduction in total branches per plant as planting population was increased. Total number of nodes per plant was statistically similar when comparing $78 \mathrm{~K}$ and $104 \mathrm{~K}$. However, both were statistically greater when compared to $130 \mathrm{~K}$ and $156 \mathrm{~K}$. Each node produced on average 2.3 pod thus, showing the importance of increase total number of nodes. Similarly, Lueschen and Hicks, (1977) reported reduced number of branches, pods, and seeds per plant when planting population was increased.

Similar to total number of nodes, total number of pods was statistically greatest when utilizing $78 \mathrm{~K}$ and $104 \mathrm{~K}$ seeding population (Table 5). $130 \mathrm{~K}$ and $156 \mathrm{~K}$ seeding population produced significantly similar total number of total pods. $78 \mathrm{~K}$ seeding rate produced $27 \%$ more total nodes and $23 \%$ more total pods when compared to $156 \mathrm{~K}$. Bruns, (2011) reported fewer total number of pods per plant when comparing 50 seed $\mathrm{m}^{-2}$ to 20 seeds $\mathrm{m}^{-2}$. However, he also concluded that total number of pods per plant may be dependent upon soybean cultivar and soil type. Bruns, (2011) reported that TR orientation decreased pods per plant. However, this data showed TR orientation increased total number of pods when pooled across all populations just not significantly (data not shown).

Stivers and Swearingin, (1980) showed that multiple short skips reduced yields less than an individual longer skip. Data concluded that skips allowed for more branching, increased pods per plant, and more pods on both main stem and branches. Twin-Row orientation allows for more space between individual plants when compared to SR which should reduce soybean competition allowing more branching and pod set. Seed yield potential on branches have proven to be as great as $40 \%$ in low planting 
populations where medium and high population branches only contributed 5 to $16 \%$ of total grain yield (Herbert and Litchfield, 1982).

TABLE 2

ANALYSIS OF VARIANCE P-VALUES FOR SOYBEAN SEED WEIGHT, PLANT HEIGHT, TOTAL PODS, TOTAL NODES, AND GRAIN YIELDS AS INFLUENCED BY PLANTING POPULATION AND ROW ORIENTATION, AND THEIR SIGNIFICANT INTERACTIONS FOR EXPERIMENTS CONDUCTED DURING 2017 AND 2018 AT THE DELTA RESEARCH AND EXTENSION CENTER

\begin{tabular}{ccccccc}
\hline \multirow{2}{*}{ Source } & Measurement \\
\cline { 3 - 6 } & df & $\begin{array}{c}\text { Seed } \\
\text { Weight }\end{array}$ & $\begin{array}{c}\text { Plant } \\
\text { Height }\end{array}$ & $\begin{array}{c}\text { Total } \\
\text { Pods }\end{array}$ & $\begin{array}{c}\text { Total } \\
\text { Nodes }\end{array}$ & $\begin{array}{c}\text { Grain } \\
\text { Yield }\end{array}$ \\
\hline \multirow{2}{*}{ Pop } & 3 & 0.1856 & 0.1200 & $\underline{0.0003 *}$ & $\underline{0.0006^{*}}$ & 0.7222 \\
Orient & 1 & $\underline{0.0022^{*}}$ & 0.4806 & 0.0805 & 0.0813 & 0.9097 \\
Pop*Orient & 3 & 0.2653 & 0.5764 & 0.0870 & 0.2324 & 0.7933 \\
\hline
\end{tabular}

TABLE 3

THE MAIN EFFECT OF ROW ORIENTATION POOLED ACROSS PLANTING POPULATION AS IT INFLUENCED SEED WEIGHT RESEARCH ESTABLISHED DURING 2017 AND 2018 AT THE DELTA RESEARCH AND EXTENSION CENTER

\begin{tabular}{ll}
\hline Row Orientation & Seed Weight ${ }^{\dagger}$ \\
\hline Single-Row & grams $/ 100$ seed \\
Twin-Row & $13.636 \mathrm{a}$ \\
\hline Means within a column followed by the same letter are not significantly different at $\mathrm{P} \leq 0.05)$.
\end{tabular}

TABLE 4

THE MAIN EFFECT OF PLANTING POPULATION POOLED ACROSS ROW ORIENTATION AS IT INFLUENCED TOTAL NUMBER OF PODS FOR RESEARCH ESTABLISHED DURING 2017 AND 2018 AT THE DELTA RESEARCH AND EXTENSION CENTER

\begin{tabular}{lccc}
\hline Seeding Rate & 2017 & 2018 & Across years \\
\hline & $-\ldots \ldots$ & $79.7 \mathrm{a}$ & $74.1 \mathrm{a}$ \\
$78 \mathrm{~K}(6 \mathrm{seed} / \mathrm{ft})$ & - & $76.2 \mathrm{a}$ & $68.3 \mathrm{a}$ \\
$104 \mathrm{~K}(8 \mathrm{seed} / \mathrm{ft})$ & $60.6 \mathrm{a}$ & $56.6 \mathrm{~b}$ & $56.6 \mathrm{~b}$ \\
$130 \mathrm{~K}(10 \mathrm{seed} / \mathrm{ft})$ & $55.9 \mathrm{a}$ & $70.5 \mathrm{ab}$ & $56.8 \mathrm{~b}$ \\
$156 \mathrm{~K}(12 \mathrm{seed} / \mathrm{ft})$ & $47.2 \mathrm{~b}$ & 12.27 & 7.53 \\
\hline LSD & 8.15 & & \\
\hline
\end{tabular}

$\dagger$ (Means within a column followed by the same letter are not significantly different at $\mathrm{P} \leq 0.05$.) 
TABLE 5

THE MAIN EFFECT OF PLANTING POPULATION POOLED ACROSS ROW ORIENTATION AS IT INFLUENCED TOTAL NUMBER OF NODES FOR RESEARCH ESTABLISHED DURING 2017 AND 2018 AT THE DELTA RESEARCH AND EXTENSION CENTER

\begin{tabular}{lccc}
\hline Seeding Rate & 2017 & 2018 & Across years \\
\hline & $-\ldots \ldots$ & $29.1 \mathrm{a}$ & $28.3 \mathrm{a}$ \\
$78 \mathrm{~K}(6 \mathrm{seed} / \mathrm{ft})$ & - & $26.0 \mathrm{a}$ & $24.5 \mathrm{a}$ \\
$104 \mathrm{~K}(8 \mathrm{seed} / \mathrm{ft})$ & $23.0 \mathrm{a}$ & $20.1 \mathrm{~b}$ & $21.1 \mathrm{~b}$ \\
$130 \mathrm{~K}(10 \mathrm{seed} / \mathrm{ft})$ & $21.7 \mathrm{a}$ & $24.6 \mathrm{ab}$ & $20.7 \mathrm{~b}$ \\
$156 \mathrm{~K}(12 \mathrm{seed} / \mathrm{ft})$ & $18.3 \mathrm{~b}$ & 4.43 & 2.87 \\
\hline LSD & 2.73 & Nodes/plant &
\end{tabular}

$\dagger$ (Means within a column followed by the same letter are not significantly different at $\mathrm{P} \leq 0.05$.)

\section{SOYBEAN GAIN YIELD}

Soybean grain yield was not significantly influenced by row orientation or planting population (Table 2). The use of TR orientation increased yield less than 1\% when compared to SR when pooled across four planting populations (Table 6). Similarly, many other studies that compared TR to SR orientation showed an increase in yield when utilizing the TR production system. Studies have shown as much as 6 to $13 \%$ increase in the respective crops when utilizing the TR orientation when compared to SR (Reddy and Boykin, (2010); Mascagni et al., (2008). Hicks et al., (1969) reported no statistical differences in grain yield when comparing 10-in to 30-in row spacing; there was also no differences in seeding rates.

When comparing $78 \mathrm{~K}$ seed per acre to $156 \mathrm{~K}$ seed per acre, seed planted was reduced by $50 \%$ but only reduced yield by $3.9 \%$ (NS). When comparing $155 \mathrm{~K}$ to $104 \mathrm{~K}$ seed per acre resulted in $33 \%$ less seed planted and only a $2.3 \%$ soybean yield reduction (NS). When comparing $156 \mathrm{~K}$ to $130 \mathrm{~K}$ resulted in $17 \%$ reduction in seed planted and only reduced soybean grain yield by $1.9 \%$ (NS) (Table 7). Similarly, Bruns, (2011) reported seeding rate did not increase soybean grain yield when planted on sandy loam soils. However, Bruns, (2011) showed seeding rate did increase soybean grain yield when planted on a clay texture soil.

TABLE 6

THE MAIN EFFECT OF ROW ORIENTATION POOLED ACROSS PLANTING POPULATION AS IT INFLUENCED SOYBEAN GRAIN YIELD FOR RESEARCH ESTABLISHED DURING 2017 AND 2018 AT THE DELTA RESEARCH AND EXTENSION CENTER

\begin{tabular}{lc}
\hline Row Orientation & Grain yield $^{\dagger}$ \\
\hline Single-Row & Bu/Acre \\
Twin-Row & 49.7 \\
\hline
\end{tabular}

LSD for row orientation (2.3)

$\dagger$ (Means within a column followed by the same letter are not significantly different at $\mathrm{P} \leq 0.05$.) 


\section{TABLE 7}

THE MAIN EFFECT OF PLANTING POPULATION POOLED ACROSS ROW ORIENTATION AS IT INFLUENCED SOYBEAN GRAIN YIELD FOR RESEARCH ESTABLISHED DURING 2017 AND 2018 AT THE DELTA RESEARCH AND EXTENSION CENTER

\begin{tabular}{lccc}
\hline Seeding Rate & 2017 & 2018 & Across years \\
\hline & $\ldots$ & 48.5 & 48.8 \\
$78 \mathrm{~K}(6 \mathrm{seed} / \mathrm{ft})$ & - & 49.0 & 49.7 \\
$104 \mathrm{~K}(8 \mathrm{seed} / \mathrm{ft})$ & 50.3 & 49.5 & 49.9 \\
$130 \mathrm{~K}(10 \mathrm{seed} / \mathrm{ft})$ & 50.3 & 50.2 & 50.8 \\
$156 \mathrm{~K}(12 \mathrm{seed} / \mathrm{ft})$ & 51.4 & 5.38 & 2.84 \\
\hline LSD & 1.18 & & \\
\hline
\end{tabular}

$\dagger$ (Means within a column followed by the same letter are not significantly different at $\mathrm{P} \leq 0.05$.)

\section{DISCUSSION AND CONCLUSION}

The objective of this study was to determine if soybean seeding rate could be reduced and determine which row orientation resulted in greatest soybean grain yield. Data has shown that populations can be reduced if stand is uniform without significantly decreasing soybean grain yield. Planting population had little effect on canopy closure; however, TR orientation always had greater canopy closure at all timings measured. Low planting populations resulted in increased number of nodes per plant as well as total number of pods per plant. Previous research concluded narrow rows less than 40-in width produce yield greater than wide rows. However, data did not indicate a significant difference during the duration of this study. After two years of data we see no significant difference in grain yield when comparing row configuration $(n=2)$ or planting population $(n=4)$. Economic analysis showed a greater net return when utilizing the lower planting populations due to greater seed cost associated with greater seeding populations.

\section{REFERENCES}

Akhanda, A.M., Prine G.M., \& Hinson K. (1976). Influence of genotype and row width on late-planted soybeans in Florida. Proc. Soil Crop Sci. Soc. Fla., 35, 21-25.

Balkcom, K.S., Satterwhite J.L., Arriaga F.J., Price A.J., \& Van Santen E. (2011). Conventional and glyphosate-resistant maize yields across plant densities in single- and twin-row configurations. Field Crops Res., 120, 330-337.

Ball, R.A., McNew R.W., Vories E.D., Kiesling T.C., \& Purcell L.C. (2001). Path analyses of population density effects on short-season soybean yield. Agron. J., 93, 187-195.

Beatty, K.D., Eldridge I.L., and Simpson A.M. (1982). Soybean response to different planting patterns and dates. Agron. J., 74, 859-862.

Boquet, D.J., Koonce K.L., \& Walker D.M. (1982). Selected determinate soybean cultivar yield responses to row spacing and planting dates. Agron. J., 74, 136-138.

Bruns, H.A. 2011. Comparisons of single-row and twin-row soybean production in the mid-south. Agron. $J ., 103,702-708$.

Cooper, R.L. (1981). Development of short-statured soybean cultivars. Crop Sci., 21, 127-131.

Costa, J.A., Oplinger E.S., \& Pendleton J.W. (1980). Response of soybean cultivars to planting patterns. Agron. J., 72, 153-156. 
Devlin, D.L., Fjell D.L., Shroyer J.P., Gordon W.B., Marsh B.H., Maddux L.D., Martin V.L., \& Duncan S.R. (1995). Row spacing and seeding rates for soybean in low and high yielding environments. J. Prod. Agric., 8, 215-222.

Dominguez, C., \& Hume D.J. (1978). Flowering, abortion, and yield of early-maturing soybean at three densities. Agron. J., 70, 801-805.

Doss, D.B., \& Thurlow D.L. 1974. Irrigation, row width, and plant population in relation to growth characteristics of two soybean varieties. Agron. J., 66, 620-623.

Elmore, R.W. (1998). Soybean Cultivar Responses to Row Spacing and Seeding Rates in Rainfed and Irrigated Environments. J. Prod. Agric., 11, 326-331.

Farnham, D.E. (2001). Row spacing, plant density, and hybrid effects on corn grian yield and moisture. Agron. J., 93, 1049-1053.

Green, D.E., Burlamaqui P.F., \& Shibles R. (1977). Performance of randomly selected soybean lines with semideterminate and indeterminate growth habit. Crop Sci., 17, 335-339.

Heatherly, L.G. (1981). Soybean response to tillage of Sharkey clay soil. Miss. State Univ. Exp. Stn. Bull. 892.

Herbert, S.J., \& Litchfield G.V. (1982). Partitioning soybean yield components. Crop Sci., 22, 1074-1079.

Hicks, D.R., Pendleton J.W., Bernard R.L., \& Johnston T.J. (1969). Response of soybean plant types to planting patterns. Agron. J., 61, 290-293.

Hoggard, A.L., Shannon J.G., \& Johnson D.R. (1978). Effect of plant population on yield and height characteristics in determinate soybeans. Agron. J., 70, 1070-1072.

Lueschen, W.E., \& Hicks D.R. (1977). Influence of plant population on field performance of three soybean cultivars. Agron. J., 69, 390-393.

Mascagni, H.J., Clawson E., Lancios D., Boquet D., \& Ferguson R. (2008). Comparing single-row, twinrow configurations for Louisiana crop production. LA Agric., 51(3), 16-17.

Reddy, K.N., \& Boykin J.C. (2010). Weed control and yield comparison of twin- and single-row glyphosate-resistant cotton production systems. Weed Technol., 24, 95-101.

Reddy, K.N., Burke I.C., Boykin J.C., \& Williford J.R. (2009). Narrow-row cotton production under irrigated and non-irrigated environment: plant population and lint yield. J. Cotton. Sci., 13, 48-55.

Ryder, G.J., \& Beuerlein J.E. (1979). A study of soybean production systems. Ohio Rep., 64(2), 19-22.

Stivers, R.K., \& Swearingin M.L. (1980). Soybean yield compensation with different populations and missing plant patterns. Agron. J., 72, 98-102.

Thurlow, D.L., \& Pitts J.H. (1983). Planting date and row spacing affects growth and yield of soybeans. Highlights Agric. Res., 30(3), 12.

Widdicombe, W.D., \& Thelen, K.D. 2002. Row width and plant density effects on corn grain production in the Northern Corn Belt. Agron. J., 94, 1020-1023.

Wilcox J.R. (1974). Response of three soybean strains to equidistant spacing. Agron. J., 66, 409-412.

Wilcox, J.R. (1980). Comparative performance of semideterminate and indeterminate soybean lines. Crop Sci., 20, 277-280. 